\title{
Congenital infections in Hong Kong: an overview of TORCH
}

\author{
Karen KY Leung, KL Hon *, Alice Yeung, Alexander KC Leung, Elim Man
}

This article was published on $2 \mathrm{Apr}$ 2020 at www.hkmj.org.

cataract, hearing loss, congenital heart disease,

\section{A B S T R A C T}

Congenital infections refer to a group of perinatal infections that may have similar clinical presentations, including rash and ocular findings. TORCH is the acronym that covers these infections (toxoplasmosis, other [syphilis], rubella, cytomegalovirus, herpes simplex virus). There are, however, other important causes of intrauterine/ perinatal infections, including enteroviruses, varicella zoster virus, Zika virus, and parvovirus B19. Intrauterine and perinatal infections are significant causes of fetal and neonatal mortality and important contributors to childhood morbidity. A high index of suspicion for congenital infections and awareness of the prominent features of the most common congenital infections can help to facilitate early diagnosis, tailor appropriate diagnostic evaluation, and if appropriate, initiate early treatments. In the absence of maternal laboratory results diagnostic of intrauterine infections, congenital infections should be suspected in newborns with certain clinical features or combinations of clinical features, including hydrops fetalis, microcephaly, seizures, hepatosplenomegaly, jaundice, or rash. Primary prevention of maternal infections during pregnancy is the cornerstone of prevention of congenital infection. Available resources should focus on the promotion of public health.

\section{Hong Kong Med J 2020;26:127-38}

https://doi.org/10.12809/hkmj198287

${ }^{1} \mathrm{KKY}$ Leung, MB, BS, MRCPCH

${ }^{1} \mathrm{KL}$ Hon *, MB, BS, MD

${ }^{2}$ A Yeung

${ }^{3}$ AKC Leung, FRCP (UK), FRCPCH

${ }^{1}$ E Man, MB, BS, MRCPCH

${ }^{1}$ Department of Paediatrics and Adolescent Medicine, The Hong Kong Children's Hospital, Kowloon Bay, Hong Kong

${ }^{2}$ Faculty of Medicine, The Chinese University of Hong Kong, Shatin, Hong Kong

${ }^{3}$ Department of Pediatrics, University of Calgary and Alberta Children's Hospital, Calgary, Canada

* Corresponding author: ehon@hotmail.com

\section{Introduction}

Congenital infections are those that can cross the placenta and damage the fetus in utero or transmit to the infant during the peripartum period of birth, resulting in neonatal infection. ${ }^{1}$ Apart from miscarriage, stillbirths, and neonatal deaths, congenital infections account for $2 \%$ to $3 \%$ of all congenital anomalies and are a significant cause of childhood morbidity. ${ }^{2-4}$ Immunologist Andres Nahmias first used the acronym ToRCH in 1971 to describe perinatal infections associated with toxoplasma (To), rubella (R), cytomegalovirus $(\mathrm{C})$, and herpes simplex virus $(\mathrm{H})$; these infections are difficult to differentiate from one another clinically. ${ }^{5}$ In 1975, Harold Fuerst proposed adding syphilis, another important congenital infection, to the list and revising the acronym into STORCH. ${ }^{6}$ Also in 1975 , Roger Brumback recommended replacing STORCH with TORCHES, as the latter term was more readily accepted and recognised by paediatricians familiar with the older acronym. ${ }^{7}$ Subsequently, the ' $O$ ' in TORCH has been broadened and now stands for 'Others' to include the following pathogens: syphilis, parvovirus, coxsackievirus, listeriosis, hepatitis virus, varicella-zoster virus, Trypanosoma cruzi, enterovirus, human immunodeficiency virus (HIV), and the latest addition, Zika virus. ${ }^{1,4}$

Congenital infections have remained a major public health issue globally, especially in developing countries. These infections can lead to significant consequences, such as severe disabilities or even fetal deaths, but most of them are preventable by preventing primary maternal infection during pregnancy. In view of this, public awareness is crucial. The World Health Organization has proposed strategies to eliminate mother-to-child transmission of HIV by 2020 and syphilis and hepatitis B by $2030 .^{8}$

This review discusses congenital infections in terms of the clinical features, medical management, implications to public health, and neurodevelopmental outcomes pertinent to the local situation. This review will focus on the classic TORCH infections: toxoplasmosis, syphilis, rubella, cytomegalovirus (CMV), and herpes simplex virus (HSV). References were searched using key terms 'congenital infection' and 'Hong Kong' or 'TORCH' and 'Hong Kong' in PubMed, limited to 'human', with no filters on article type or publication date. Discussion is based on, but not limited to, the search results. 


\section{香港TORCH先天性感染概述}

\section{梁嘉恩、韓錦倫、楊雅詩、梁國柱、文爾琳}

先天性感染指一組圍產期感染, 可能具有包括皮疹和眼部表徵等相 似臨床表現。這些感染簡稱TORCH（T指弓形蟲, O指其他包括梅 毒, $R$ 指德國麻疹, $C$ 指巨細胞病毒, $H$ 指單純皰疹病毒）。其他重 要的宮內和圍產期感染原因包括腸病毒、水痘帶狀皰疹病毒、寨卡 病毒和細小病毒B 19 。宮內和圍產期感染是造成胎兒和新生兒死亡的 主因, 並且是造成兒童發病率的重要因素。對先天性感染保持高度警 覺, 以及對最常見先天性感染重要特徵的認識有助早期診斷, 制定適 當的診斷評估以適時啟動早期治療。在沒有作為診斷宮內感染的孕產 婦實驗室結果的情況下, 當發現以下新生兒先天性感染的臨床特徵或 臨床特徵組合時應提高警覺, 包括胎兒積水、小頭畸形、癲痆發作、 白內障、聽力下降、先天性心臟病、肝脾腫大、黃疸或皮疹。初級預 防孕產婦感染是預防先天性感染的基石。建議現有資源應以推廣公共 衛生為重點。
Hong Kong was reported to be 9.8\%; this low rate is probably attributed to the local habit of eating wellcooked meat as part of traditional Chinese meals and the relatively low number of households that keep cats as pets. ${ }^{13}$ The estimated global incidence of congenital toxoplasmosis is approximately 190100 cases annually, with an incidence rate of approximately 1.5 cases per 1000 live births. ${ }^{14}$

Although congenital toxoplasmosis is asymptomatic in approximately $75 \%$ of affected newborns, common manifestations in symptomatic neonates include fever, maculopapular rash, chorioretinitis, intracranial calcification, hydrocephalus, abnormal cerebrospinal fluid (CSF), jaundice, thrombocytopenia, anaemia, hepatosplenomegaly, lymphadenopathy, pneumonitis, seizures, microphthalmia, and microcephaly. ${ }^{10,15}$ The classic triad of chorioretinitis, hydrocephalus, and intracranial calcifications occur in less than $10 \%$ of cases of congenital toxoplasmosis. ${ }^{16}$ Infants who are asymptomatic at birth may develop chorioretinitis, blindness, cerebral palsy, cerebellar dysfunction, microcephaly, seizures, mental retardation, sensorineural deafness, or growth retardation later in life, and untreated cases are at higher risk of developing these serious sequelae. ${ }^{17,18}$

Acute maternal infection with $T$ gondii is usually asymptomatic. Symptoms include transient, mild fever, headaches, myalgias, maculopapular rash, sore throat, lymphadenopathy, and hepatomegaly. When toxoplasmosis is suspected, three tests can be performed for prenatal diagnosis. Serological tests to detect the levels of Toxoplasma-specific immunoglobulin G (IgG) and IgM antibodies in the maternal serum are widely used to assess immunity to the parasite and any recent infection in the pregnant mother. After infection, IgG appears in 1 to 2 weeks and persists throughout life, therefore leading to immunity in the mother. In contrast, IgM becomes detectable earlier after infection than IgG and persists for a variable period from months to years, such that positive results for both IgG and IgM antibodies can be difficult to interpret. ${ }^{9}$ Ultrasonography of affected fetuses can be normal or non-specific, but intracranial calcifications, ventricular dilatations, hepatic enlargement, ascites, and increased placental thickness are present in approximately $6 \%$ of infected fetuses. ${ }^{19,20}$ Because maternal infection does not necessarily result in fetal infection, suspected or established maternal infection should be confirmed prenatally by polymerase chain reaction (PCR) amplification of Toxoplasma DNA in amniotic fluid. Diagnostic performance after 18 weeks of gestation and at least 4 weeks after maternal seroconversion is likely to be more reliable. ${ }^{10,21}$

Postnatal diagnosis of congenital toxoplasmosis can be confirmed by detection of $T$ gondii in the 
infant's umbilical cord blood, urine, peripheral blood, or CSF; Toxoplasma DNA in the infant's amniotic fluid, peripheral blood, urine, or CSF; IgG, IgM, and IgA antibodies in peripheral blood or CSF; or Toxoplasma IgG antibody at 12 months of life. For infants positive for IgG but negative for $\operatorname{IgM}$ and IgA, follow-up serology testing for IgG should be repeated every 4 to 6 weeks until complete disappearance of IgG. 9,21,22

When primary maternal infection is diagnosed before 18 weeks of gestation, antiparasitic treatment with spiramycin should be initiated as soon as possible to prevent transplacental transmission. ${ }^{9,10}$ If PCR on amniotic fluid is positive for $T$ gondii DNA after 18 weeks of gestation, treatment should be replaced by pyrimethamine-sulfadiazine with leucovorin (folinic acid). If PCR is negative, following the prophylaxis regimen in the US and France, continuation of spiramycin is recommended until delivery; or following the prophylaxis regimen in Austria and Germany, spiramycin is used by a 4-week course of pyrimethamine-sulfadiazine at 17 weeks of gestation. ${ }^{10}$

For infants with symptomatic congenital toxoplasmosis, a 12-month treatment with pyrimethamine-sulfadiazine is indicated. Folinic acid is also given to minimise pyrimethamine toxicity. ${ }^{10,22}$ As sulfadiazine is not available in Hong Kong, clindamycin can be used instead..$^{23}$ The same regimen is used for asymptomatic infants, but the treatment duration is 3 months. ${ }^{22}$

Education on prevention of Toxoplasma infection is important for pregnant mothers. They should be advised to avoid eating raw or undercooked meat/shellfish or drinking unfiltered water; to clean fruits and vegetables thoroughly before consumption ${ }^{24}$; and to employ proper hand hygiene to reduce the risk of infection. ${ }^{25}$ If the family keeps cats as pets, the cats should not be fed raw or undercooked meat and contact with cat litter should be avoided. ${ }^{26}$

Universal screening for maternal toxoplasmosis is incorporated into the maternalchild care programme in some countries, including Austria, France, and Italy. ${ }^{27}$ However, such screening is not practised in the US, Canada, or the United Kingdom, mainly because of the lower prevalence of toxoplasmosis, uncertainty about the effectiveness of maternal treatment at preventing congenital infection, high cost of frequent testing required for early detection of infections, low screening sensitivity, cost-ineffectiveness of treating women with false positive results, and possible low adherence to frequent rescreening. ${ }^{28,29}$ In Hong Kong, as the prevalence of toxoplasmosis and the cost effectiveness of antenatal screening for toxoplasmosis are relatively low, patient education for prevention of
Toxoplasma infection should be sufficient to reduce the risk of congenital toxoplasmosis.

\section{O - Congenital syphilis}

Syphilis is a sexually transmitted disease caused by Treponema pallidum, a spirochete. Congenital syphilis affects approximately 2 million pregnancies annually, and approximately $25 \%$ of these pregnancies result in spontaneous abortion or stillbirths. ${ }^{30}$

Syphilis is not a notifiable disease in Hong Kong. The Social Hygiene Service reported only 100 new cases in 1991, increasing to 1095 cases in 2018, accounting for 14.6 cases per 100000 population. ${ }^{31}$ This is much higher than the 9.5 cases per 100000 population reported in the US in $2017 .^{32}$ In Hong Kong, congenital syphilis decreased from over 100 new cases annually in the early 1970 s to three cases of congenital syphilis in 2017, 0 cases in 2018, and one case in 2019 (through August). All recent reported cases were late congenital syphilis. ${ }^{31}$

Congenital syphilis usually results from transplacental transmission of $T$ pallidum, mostly in untreated or inadequately treated mothers, especially with concomitant HIV infection. The risk of fetal infection increases along with the progression of gestation. ${ }^{9}$ In contrast, the risk of vertical transmission in untreated mothers is highest during the first stage and lowest in the late stage. ${ }^{33}$

Congenital syphilis can result in spontaneous abortion (usually after the first trimester), stillbirth, premature birth, impaired fetal growth, and neonatal mortality. ${ }^{9,34}$ Approximately two thirds of infected neonates born alive are asymptomatic at birth.,934 However, symptoms usually develop by the third month if these infants are left untreated. ${ }^{35}$

Congenital syphilis can be divided into two stages: early congenital syphilis with symptoms onset during the first 2 years of life and late congenital syphilis with manifestations after age 2 years. ${ }^{35}$ Hepatomegaly with or without splenomegaly, jaundice, syphilitic rhinitis (snuffles), maculopapular and vesicular rash, generalised lymphadenopathy, osteochondritis, and periostitis are common manifestations of early congenital syphilis. ${ }^{9,36}$ Other manifestations of early congenital syphilis include non-immune hydrops fetalis, fever, pneumonia, secondary sepsis, myocarditis, inability to move an extremity because of pain ("pseudoparalysis of Parrot"), chorioretinitis, cataract, glaucoma, loss of eyebrows, uveitis, nephrotic syndrome, rectal bleeding from ileitis, malabsorption, keratoderma of the hands and feet, and onychauxis of the fingernails and toenails. ${ }^{37-39}$ Laboratory abnormalities may include anaemia, thrombocytopenia, leukopenia, and leukocytosis. Radiological abnormalities may include erosions (osseous destruction) and lucencies (demineralisation) of the proximal medial tibial 
metaphysis (Wimberger sign), metaphyseal lucent bands, metaphyseal serrated appearance at the epiphyseal margin of long bones (Wegner sign), irregular areas of increased density and rarefaction ('moth-eaten' appearance), diaphyseal periostitis, and multiple sites of osteochondritis. ${ }^{40}$

Late congenital syphilis occurs in approximately $40 \%$ of untreated infants and is often related to scarring and deformities resulting from early infection. ${ }^{9}$ Manifestations include saddle nose; perioral fissures (rhagades); frontal bossing; Clutton joints (symmetrical, sterile, and painless synovial effusions); thickening of sternoclavicular joint (Higoumenakis sign); scaphoid scapula; anterior bowing of shins (saber shins); perforation of the hard palate; multicusped first molars (mulberry molars); peg-shaped, notched, widely spaced permanent upper central incisors (Hutchinson's teeth); interstitial keratitis; glaucoma; mental retardation; sensorineural deafness; and hydrocephalus. ${ }^{9,36,37}$ Hutchinson's triad, including Hutchinson's teeth, interstitial keratitis, and sensorineural deafness, specific to late congenital syphilis, is rather rare. ${ }^{36}$

Diagnosis of gestational syphilis can be established by serological tests, including both non-treponemal (rapid plasma regain [RPR] and venereal disease research laboratory [VDRL]) and treponemal tests ( $T$ pallidum particle agglutination and automated treponemal assay, eg enzyme immunoassay). Non-treponemal assays are recommended for screening, followed by a treponemal test if the screening result is positive. If the reverse sequence screening algorithm is used and the pregnant woman is reactive to the treponemal test, confirmatory testing with a non-treponemal test should be performed. However, if these two results are discordant, a different treponemal test using a different $T$ pallidum should be performed. ${ }^{22}$ Nonspecific ultrasonographic abnormalities include hepatomegaly, placentomegaly, polyhydramnios, and hydrops fetalis. ${ }^{36}$ Congenital syphilis should be suspected in infants with a history of untreated or inadequately treated maternal syphilis, especially when they have a reactive treponemal test, and the physical examination showing signs of infection, abnormal long bone radiography, elevated cell count, protein in the CSF, or a quantitative non-treponemal test with titre at least four-fold higher than that of the mother. Diagnosis can be established by the presence of $T$ pallidum in body fluids or samples from lesions when viewed by dark-field microscopy or fluorescent antibody staining. ${ }^{41}$

Parenterally administered penicillin $G$ is the standard treatment for syphilis. ${ }^{41}$ Pregnant patients with immediate-type penicillin allergy should be treated with penicillin after desensitisation because there is no satisfactory alternative for treating syphilis in pregnancy. ${ }^{41}$ The overall success rate of maternal treatment at all gestational ages in preventing congenital syphilis is as high as $98 \%$ and maternal secondary syphilis has the highest risk of fetal treatment failure compared with other stages of maternal infection. ${ }^{42}$ Mother-to-child infection is more likely to occur in adequately treated mothers in the conditions that the interval from treatment to delivery is short ( $<30$ days), stage of maternal infection is early, delivery occurs before 36 weeks of gestation, or non-treponemal titre is high at the initiation of treatment and delivery. ${ }^{43}$

If congenital syphilis is diagnosed or suspected in an infant, treatment can be made with reference to the mother's treatment history for syphilis, the infant's physical examination findings, and maternal and infant RPR/VDRL titres. For proven or highly probable congenital syphilis, penicillin G should be given intravenously for 10 days. ${ }^{22,41}$ For possible congenital syphilis cases with either incomplete or abnormal evaluations, the same regimen should be administered. In cases where congenital syphilis is less likely positive (eg, infant RPR/VDRL are less than four-fold of the maternal RPR/VDRL), the infant should be followed-up every 3 months until nontreponemal tests become non-reactive; alternatively, a single dose of penicillin $\mathrm{G}$ can be given. ${ }^{22}$

Screening for syphilis during early pregnancy remains an important preventive measure against congenital syphilis since early diagnosis facilitates timely treatment that can prevent perinatal loss and potential severe disabilities. ${ }^{44}$ In Hong Kong and many other countries, the VDRL test for syphilis is performed during the first antenatal visit.

\section{$R$ - Congenital rubella}

Rubella, also known as German measles, is a viral illness that is often mild or even asymptomatic when acquired. However, catastrophic consequences may result from congenital infections and is therefore of particular concern in pregnant women.

Rubella has been a notifiable disease in Hong Kong since 1994, and the number of cases has fluctuated drastically, from eight cases in 1994 up to 4958 cases in $1997 .{ }^{45}$ After a spike of 2338 cases recorded in 2000, the number of rubella cases has decreased and remained low in recent years. There were 11 reported cases in 2018 and 46 cases in 2019 (through August). ${ }^{46}$ From 2001 to 2019, there were only four reported cases of congenital rubella syndrome (CRS): one in 2008 and three in $2012 .{ }^{46}$ The three cases in 2012 were mothers born in mainland China who had either uncertain proof or no history of rubella vaccination. ${ }^{45}$

Although rubella virus can spread by a respiratory route, vertical transmission from an infected mother to her fetus can occur via haematogenous spread during maternal viraemia. The risk of transmission differs depending on the 
timing of maternal infection. ${ }^{47}$ A study conducted in England from 1976 to 1978 found that when maternal infection occurred within the first 12 weeks of gestation, the fetal infection rate reached $>80 \%$; at the end of second trimester, it could drop to $25 \%$; at 27 to 30 weeks, it could be $35 \%$; and when it occurred during the last month of gestation, the rate could get close to $100 \%{ }^{48}$

Rubella infection has an incubation period of 14 to 21 days and can be asymptomatic (ie, subclinical) in $25 \%$ to $50 \%$ of individuals. ${ }^{49}$ When symptoms occur, they are usually mild and selflimiting. Prodromal symptoms include low-grade fever, malaise, anorexia, nausea, non-exudative conjunctivitis, coryza, cough, sore throat, headache, petechiae on the soft palate (Forchheimer spots) and postauricular area, and occipital and/or posterior cervical lymphadenopathy. ${ }^{47,49}$ These symptoms, though common in adolescents and adults, are unusual in children. ${ }^{47}$ Prodromal symptoms are usually followed by the characteristic pinpoint, erythematous, maculopapular rash in 50\% to $80 \%$ of cases, starting on the face, later spreading to the trunk and limbs, and becoming generalised within 24 hours. ${ }^{47}$ The rash usually subsides in 3 days and fades in the same directional pattern as it appears. Some individuals, mostly adolescents and adult women, may also experience polyarthritis and polyarthralgia approximately 1 week after the rash. ${ }^{49}$

Maternal rubella infection during the first 8 to 10 weeks of gestation can lead to catastrophic consequences, including spontaneous abortion, stillbirth, and prematurity. ${ }^{9,50,51}$ Cataracts, congenital heart defects (eg, patent ductus arteriosus, branch pulmonary artery hypoplasia/ stenosis), and sensorineural hearing loss are the classic triad of CRS.47 Other manifestations of CRS include intrauterine growth retardation, retinopathy, infantile glaucoma, mental retardation, microcephaly, meningoencephalitis, hepatitis, hepatomegaly, splenomegaly, haemolytic anaemia, thrombocytopenia, and purpura ("blueberry muffin spots"). ${ }^{9,50-52}$ Some of these clinical manifestations are transient and non-specific; others may evolve over time into adulthood, even when the infection is subclinical at birth. $.50-52$ The risk of congenital defects after maternal infection is essentially limited to the first 16 weeks of gestation. Beyond 20 weeks of gestation, focal growth restriction seems to be the only significant sequela. ${ }^{49}$

Diagnosis of maternal infection can be confirmed by using serological tests when there is a four-fold increase in rubella-specific IgG titre between acute and convalescent serum samples, a positive test for rubella-specific IgM antibodies, or a positive culture for the rubella virus. ${ }^{49}$ Fetal infection can be confirmed with a positive PCR assay on a chorionic villus sample when other clinical findings are consistent with the features of congenital rubella. ${ }^{49}$ If congenital rubella infection is suspected, the diagnosis can be confirmed by the presence of rubella-specific IgM antibodies in the cord blood or neonatal serum within the first 6 months of life, detection of rubella virus RNA by reverse transcription PCR on nasopharyngeal swab or urine, or isolation of the rubella virus..$^{47,53}$

No specific antiviral treatment for rubella is now available. When maternal rubella is confirmed before 20 weeks of gestation, treatment with Ig and termination of pregnancy should be discussed as options based on local legislation. ${ }^{47}$ Treatment of CRS mainly involves long-term interdisciplinary supportive care for managing clinical manifestations, close monitoring of neurodevelopmental progress, and long-term audiological and ophthalmic followup. ${ }^{47}$

Vaccination is the only practical and effective way of preventing congenital rubella infection; a single dose of vaccine can offer long-lasting immunity in $>95 \%$ of cases, while two doses given at an appropriate interval offers close to $100 \%$ protection. ${ }^{47,52}$ While the rubella vaccine is available as an isolated vaccine, it is often administered as a combined vaccine with measles (MR), both measles and mumps (MMR), or together with varicella (MMRV). Yet the vaccine is contra-indicated in pregnant women because of potential transplacental transfer of live rubella virus. Since 1969 the immunisation against rubella with live, attenuated virus was first introduced, some countries have implemented national immunisation programmes against rubella although no cases of CRS have been reported due to rubella vaccination during early pregnancy, ${ }^{54,55}$ the number of cases of rubella infection has declined globally.

Under the Hong Kong Childhood Immunisation Programme, the inclusion of eligible children who are entitled to free immunisation against 11 infectious diseases including rubella has been incorporated into the programme progressively since $1978{ }^{45}$ Starting from 1982, the two-dose protocol has covered all eligible children in Hong Kong. The first dose of MMR vaccine is given at age 1 year, and the second dose at primary one. The second dose of MMR vaccine has been replaced with MMRV vaccine for children born on or after 1 January 2013. The estimated coverage of the first dose of MMR vaccine in children from aged 2 to 5 years remains high (over 98\%). ${ }^{56}$

Screening for rubella IgG antibodies is performed in pregnant women during their first antenatal visit. If the pregnant woman is found to be non-immune to rubella during the screening, postpartum vaccination is arranged at the Maternal Child Health Centre to protect the mother and her future pregnancies. With universal immunisation against rubella implemented in Hong Kong, the 
seronegativity rate among resident women who delivered their babies in a local hospital was $8.1 \%$, less than half of the non-residents being $19.9 \%$, who were mostly Chinese from the mainland China where there is no such immunisation programme implemented. ${ }^{57}$

\section{C - Congenital cytomegalovirus}

Cytomegalovirus is a ubiquitous herpesvirus that can reside in the body after a primary infection throughout the person's life. ${ }^{9}$ Non-primary infection can result from reactivation of the latent virus or reinfection by a different strain of CMV. Approximately $1 \%$ to $7 \%$ of pregnant women acquire primary CMV infection; of these, about $30 \%$ to $40 \%$ transmit the infection to the fetus. ${ }^{58,59}$ Congenital CMV infection represents the most common congenital viral infection worldwide and is a leading cause of hearing loss and neurological disabilities in children. ${ }^{60,61}$

According to the Centre for Health Protection of Hong Kong, the seroprevalence rates of CMV antibodies in local women aged between 20 and 39 years ranged from $50 \%$ to $86 \%$ in 2015 , with the highest rate in the age-group of 35 to 39 years. ${ }^{62} \mathrm{~A}$ local study of Chinese women in Hong Kong found a $7.4 \%$ prevalence rate of CMV in cervical excretions during the third trimester, which was low relative to other Asian countries. ${ }^{63}$ A 1994 report indicated that the seroprevalence rate of CMV in Hong Kong increased steadily from $37 \%$ at aged 1 year to $51 \%$ by aged 10 years and increased drastically to almost $100 \%$ by aged 21 years, implying that CMV infection is usually acquired early in life. ${ }^{64}$

Cytomegalovirus can be transmitted through direct or indirect contact with infectious body fluids like saliva, urine, blood, semen, or cervical or vaginal secretions. ${ }^{60}$ Maternal CMV infection is mainly acquired through contact with the urine or saliva of infected individuals or sexual contact. $^{60}$ Cytomegalovirus can be transmitted transplacentally, resulting in congenital infection, with the transmission rate reaching approximately $32.3 \%$ in mothers with primary infection but only $1.4 \%$ in those with non-primary infection. ${ }^{65}$ Despite the higher rate of vertical transmission and the fact that many women of childbearing age are seropositive for CMV, only one-quarter of congenital CMV infections are caused by primary maternal infection, with the rest three-quarters resulting from non-primary maternal infections. ${ }^{66}$ The risk of vertical transmission is approximately $36 \%$ when the primary maternal infection occurs during the first trimester, whereas in the third trimester ${ }^{67}$ rise to 77.6\%.

Primary CMV infection in immunocompetent individuals is asymptomatic including $75 \%$ to $95 \%$ of pregnant women with infection. ${ }^{9,68}$ In others, it may present as a mild mononucleosis- or flu-like syndrome with non-specific symptoms such as fever and fatigue. ${ }^{68}$ Nevertheless, congenital CMV infections can have severe disabling consequences.

Congenital CMV infections from primary maternal infections are more likely to result in symptoms and long-term defects in neonates than those from non-primary maternal infections. ${ }^{58-69}$ Approximately $10 \%$ of newborns congenitally infected with CMV are symptomatic. ${ }^{65}$ The most common manifestations are jaundice at birth, petechiae, hepatosplenomegaly, small size for age, and microcephaly. ${ }^{60}$ Other clinical manifestations include premature birth, hypotonia, poor feeding, lethargy, sensorineural hearing loss, chorioretinitis, hydrocephalus, seizures, thrombocytopenia, anaemia, and pneumonitis. ${ }^{60,69}$

The risk of developing central nervous system (CNS) sequelae is higher if the congenital infection results from primary maternal infection occurring in the first trimester than later stage in pregnancy. ${ }^{70}$ The development of permanent sequelae is more frequent in symptomatic newborns, while $10 \%$ to $15 \%$ of those who are asymptomatic at birth have developmental abnormalities including sensorineural hearing loss, microcephaly, motor defects, mental retardation, chorioretinitis, and dental defects, usually appearing before the age of 2 years. ${ }^{9,61,71}$ For instance, while nearly $50 \%$ of symptomatic neonates develop sensorineural hearing loss, only $7 \%$ of asymptomatic ones develop it. ${ }^{72}$ Fetal and neonatal deaths can also result from congenital CMV infections in approximately $0.5 \%$ of cases. ${ }^{71}$

A history of maternal primary CMV infection, together with ultrasonography findings such as echogenic bowel, bilateral periventricular cerebral calcifications, hydrocephalus, microcephaly, fetal growth retardation, oligohydramnios, polyhydramnios, placentomegaly, hepatosplenomegaly, hepatic calcifications, ascites, or hydrops, are suggestive of fetal infection. ${ }^{71}$ Fetal CMV infection can be diagnosed by PCR for CMV DNA and virus isolation from the amniotic fluid, but PCR does not predict adverse fetal outcomes. ${ }^{68}$ As for newborns, isolation of CMV in the infant's urine within the first 2 weeks of life is the standard for diagnosing congenital infection. ${ }^{59}$

While no prenatal treatment has yet been shown to reduce in-utero infections or sequelae, antiviral treatment with ganciclovir and valganciclovir has been proven to reduce the risk of sensorineural hearing loss and improve neurodevelopmental outcomes, especially when treatment is initiated within the first month after birth in symptomatic infants and continued for 6 months. ${ }^{73}$ Meanwhile, more evidence is needed to justify the risks and benefits of antiviral treatment in asymptomatic infants to devise a suitable treatment scheme that 
helps to minimise the risk of development of severe sequelae later in life.

Currently, systemic screening for CMV primary infection is not performed in any one country. ${ }^{59}$ Risk reduction strategies should focus on preventing maternal primary infection during pregnancy. Thus, proper hygiene practices (eg, hand washing), reducing maternal exposure to body fluids that contain the virus (eg, saliva and urine of children with infection), and access to clean running water are effective measures to reduce CMV infections. ${ }^{60}$

\section{$\mathrm{H}$ - Congenital herpes simplex virus}

Herpes simplex viruses types 1 and 2 are herpesviruses, which can establish lifelong latency after the primary infection. ${ }^{74,75}$ Both types of HSV can cause genital herpes, which when acquired during pregnancy may pose a risk of vertical transmission to the neonate. ${ }^{76}$ Neonatal HSV infection is estimated to occur in 1 in 3000 to 20000 livebirths, but it is rare in Hong Kong, with only one case of neonatal HSV type 1 infection reported from 2008 to $2010 .{ }^{75,77}$

In Hong Kong, HSV infection tends to be acquired early in life, with a gradual rise in seropositivity in childhood and a drastic rise in young adults. ${ }^{64}$ Infection with HSV occurs through direct contact of mucosal or abraded skin surfaces with infectious secretions or lesions, commonly found in the oral and genital regions. ${ }^{9}$ Approximately $5 \%$ of neonatal HSV infections occur in utero, $85 \%$ during the peripartum period, and the remaining 10\% postnatally, through direct contact with infectious lesions or secretions. ${ }^{78}$ Peripartum infection is mainly caused by direct contact with infected genital lesions in the birth canal. ${ }^{79,80}$ The risk of vertical transmission is higher in mothers with newly acquired genital HSV infections than those with HSV reactivation, with $57 \%$ and $2 \%$ increases in risk, respectively. ${ }^{79-81}$ The presence of maternal antibodies to either HSV subtype seems to offer a certain degree of protection against neonatal transmission. Even antibodies against HSV-2 seem to have a protective effect against neonatal transmission of both HSV subtypes, women of all HSV serological statuses can transmit the virus to neonates. ${ }^{79} \mathrm{Genital}$ infection occurring closer to term incurs a higher risk of neonatal transmission, with $50 \%$ to $80 \%$ risk of neonatal infections resulting from maternal genital HSV infections close to term. ${ }^{79}$

The majority of both newly acquired or recurrent genital HSV infections are asymptomatic or too mild to be recognised or properly diagnosed, such that no known history of genital HSV infection was found in close to $80 \%$ of mothers who delivered an infected infant. ${ }^{9,82}$

In-utero HSV infection accounts for only $5 \%$ of all neonatal HSV infections. ${ }^{9}$ The triad of cutaneous, CNS, and ophthalmic findings are typical in this group of infants. Common cutaneous presentations include vesicles, scarring, aplasia cutis, and hypopigmentation/hyperpigmentation. Neurological findings include microcephaly, intracranial calcifications, and hydranencephaly, while ophthalmic manifestations typically include chorioretinitis, microphthalmia, and optic atrophy. ${ }^{9,76}$

Peripartum and postnatal HSV infections share similar clinical manifestations. They can generally be categorised into three main groups: disease localised to the skin, eyes, or mouth (SEM disease); disease localised to the CNS (CNS disease); and disseminated disease. ${ }^{78}$ Approximately $45 \%$ of all cases are categorised as SEM disease, and these cases typically include vesicles on the skin, keratoconjunctivitis of the eye, and infection of the oropharynx. Approximately $30 \%$ of cases are categorised as CNS disease, which is mainly caused by meningoencephalitis and can present with focal or generalised seizures, fever, lethargy, irritability, tremors, poor oral intake, temperature instability, bulging fontanelle, or pyramidal tract signs..$^{9,78}$ Disseminated disease involving multiple visceral organs, such as the lungs, liver, heart, and brain, occurs in the remaining $25 \%$ of cases. $^{78}$ It presents with irritability, seizures, respiratory failure, hepatic failure, jaundice, disseminated intravascular coagulopathy, and shock. Disseminated disease is associated with a mortality rate of $29 \% .{ }^{78}$

Diagnosis of neonatal HSV infection is challenging because of its non-specific presentation. All of the following specimens should be obtained and sent for PCR assay: surface specimens (mouth, nasopharynx, conjunctivae, anus), skin vesicles, CSF, and whole blood..$^{22}$ Other organ involvement can be screened by laboratory tests and imaging, such as alanine transaminase levels as indicator of hepatic involvement; chest X-ray for lung involvement; and neuroimaging and electroencephalogram as indicators of CNS disease.

Antiviral treatment with intravenous acyclovir is recommended for neonates with HSV infection. For infants with disseminated or CNS disease, 21 days of antiviral therapy are indicated. For those with SEM disease, 14 days of treatment is recommended. ${ }^{22}$ The 14-day treatment is also recommended for asymptomatic neonates born to mothers who are infected with HSV close to term. ${ }^{22}$ The emergence of antiviral treatment for HSV infection has contributed to a drastic reduction in the 12-month mortality rate of infants with disseminated HSV disease, from $85 \%$ to $29 \%$ overall, and from $50 \%$ to only $4 \%$ in those with CNS disease. ${ }^{78,80}$ Morbidity rates and long-term outcomes have also been improved with the use of antiviral agents, especially when treatment is initiated as soon as possible with an early diagnosis. ${ }^{9,78}$ 
TABLE. Summary of clinical manifestations, diagnostic workup, and treatment for different TORCH infections

\begin{tabular}{|c|c|c|c|c|c|}
\hline & $\begin{array}{l}\text { Congenital } \\
\text { toxoplasmosis }\end{array}$ & $\begin{array}{l}\text { Congenital } \\
\text { syphilis }^{9,31,36,41}\end{array}$ & $\begin{array}{l}\text { Congenital } \\
\text { rubella } 9,47,50,53,57\end{array}$ & $\begin{array}{l}\text { Congenital } \\
\text { cytomegalovirus }^{9,22,53,69,71,84}\end{array}$ & $\begin{array}{l}\text { Congenital herpes } \\
\text { simplex virus } \\
\text { infection }^{22,81,84}\end{array}$ \\
\hline $\begin{array}{l}\text { Seroprevalence } \\
\text { in women in } \\
\text { Hong Kong }\end{array}$ & $2.4 \%-9.8 \%$ & No data & $92 \%$ & $50 \%-87.5 \%$ & $\begin{array}{l}\text { HSV-1: } 80 \%-90 \% \\
\text { HSV-2 ( } \geq 25 \text { years): } \\
17 \%-18 \%\end{array}$ \\
\hline $\begin{array}{l}\text { Prevalence in } \\
\text { Hong Kong }\end{array}$ & No data & $\begin{array}{l}\text { 14.6 Cases per } 100000 \\
\text { population }\end{array}$ & No data & No data & $\begin{array}{l}\text { Rare, less than } 1 \\
\text { reported case per year }\end{array}$ \\
\hline $\begin{array}{l}\text { Congenital } \\
\text { infection clinical } \\
\text { features }\end{array}$ & $\begin{array}{l}\text { - Asymptomatic in } 75 \% \\
\text { - Intracranial calcifications } \\
\text { - Microcephaly } \\
\text { - Sensorineural deafness } \\
\text { - Seizures } \\
\text { - Hydrocephalus } \\
\text { - Microphthalmia } \\
\text { - Chorioretinitis } \\
\text { - Pneumonitis } \\
\text { - Jaundice } \\
\text { - Maculopapular rash } \\
\text { - Hepatosplenomegaly } \\
\text { - Lymphoadenopathy } \\
\text { - Anaemia } \\
\text { - Thrombocytopenia }\end{array}$ & $\begin{array}{l}\text { - Asymptomatic in 66\% } \\
\text { - Early (present before } 2 \\
\text { years) } \\
\text { o Fulminant } \\
\text { disseminated } \\
\text { infection } \\
\text { o Osteochondritis } \\
\text { o Periostitis } \\
\text { o Syphilitic rhinitis } \\
\text { o Hepatomegaly } \\
\text { o Splenomegaly } \\
\text { o Jaundice } \\
\text { o Maculopapular and } \\
\text { vesicular rash } \\
\text { o Lymphadenopathy } \\
\text { o Anaemia } \\
\text { o Thrombocytopenia } \\
\text { o Leukopenia } \\
\text { - Late (present after } 2 \\
\text { years) } \\
\text { o Frontal bossing } \\
\text { o Interstitial keratitis } \\
\text { o Glaucoma } \\
\text { o Saddle nose } \\
\text { o Perioral fissures } \\
\text { o Hutchinson's teeth } \\
\text { o Neurosyphillis }\end{array}$ & $\begin{array}{l}\text { - Microcephaly } \\
\text { - Cataracts } \\
\text { - Meningoencephalitis } \\
\text { - Infantile glaucoma } \\
\text { - Retinopathy } \\
\text { - Congenital heart defects } \\
\text { (eg, patent ductus } \\
\text { arteriosus, branch } \\
\text { pulmonary artery } \\
\text { hypoplasia/stenosis) } \\
\text { - Intrauterine growth } \\
\text { retardation } \\
\text { - Hepatitis } \\
\text { - Hepatomegaly } \\
\text { - Splenomegaly } \\
\text { - Haemolytic anaemia } \\
\text { - Thrombocytopenia } \\
\text { - Purpura }\end{array}$ & $\begin{array}{l}\text { - Asymptomatic in } 90 \% \\
\text { - Microcephaly } \\
\text { - Intracerebral (typically } \\
\text { periventricular) } \\
\text { calcification } \\
\text { - Hydrocephalus } \\
\text { - Seizures } \\
\text { - Hypotonia } \\
\text { - Chorioretinitis } \\
\text { - Sensorineural hearing } \\
\text { loss } \\
\text { - Jaundice at birth } \\
\text { - Pneumonitis } \\
\text { - Hepatosplenomegaly } \\
\text { - Small size for age } \\
\text { - Anaemia } \\
\text { - Thrombocytopenia } \\
\text { - Petechiae }\end{array}$ & $\begin{array}{l}\text { Localised (skin, eyes, } \\
\text { and mouth) } \\
\text { - Skin vesicles } \\
\text { - Keratoconjunctivitis } \\
\text { of the eye } \\
\text { - Infection of the } \\
\text { oropharynx } \\
\text { - Aplasia cutis } \\
\text { - Hypopigmentation/ } \\
\text { hyperpigmentation } \\
\text { CNS disease } \\
\text { - Bulging fontanelle } \\
\text { - Seizures } \\
\text { - Fever } \\
\text { - Lethargy } \\
\text { - Irritability } \\
\text { - Tremors } \\
\text { - Temperature } \\
\text { instability } \\
\text { - Pyramidal tract signs } \\
\text { Disseminated disease } \\
\text { - Seizures } \\
\text { - Respiratory failure } \\
\text { - Hepatic failure } \\
\text { - Disseminated } \\
\text { intravascular } \\
\text { coagulopathy } \\
\text { - Shock }\end{array}$ \\
\hline Morbidity & $\begin{array}{l}\text { - Blindness } \\
\text { - Cerebral palsy } \\
\text { - Cerebellar dysfunction } \\
\text { - Mental retardation } \\
\text { - Sensorineural deafness } \\
\text { - Growth retardation }\end{array}$ & $\begin{array}{l}\text { - Mental retardation } \\
\text { - Sensorineural hearing } \\
\text { loss }\end{array}$ & $\begin{array}{l}\text { - Mental retardation } \\
\text { - Sensorineural hearing } \\
\text { loss }\end{array}$ & $\begin{array}{l}\text { - Sensorineural hearing } \\
\text { loss } \\
\text { - Developmental delay } \\
\text { - Mental retardation } \\
\text { - Dental defects }\end{array}$ & $\begin{array}{l}\text { - Microcephaly } \\
\text { - Intracranial } \\
\text { calcifications } \\
\text { - Hydranencephaly } \\
\text { - Chorioretinitis } \\
\text { - Microphthalmia } \\
\text { - Optic atrophy }\end{array}$ \\
\hline $\begin{array}{l}\text { Antenatal } \\
\text { screening in } \\
\text { Hong Kong }\end{array}$ & Not routine & $\begin{array}{l}\text { Routine screening } \\
\text { (1) Initial screening } \\
\text { - Non-treponemal } \\
\text { essay (eg, RPR and } \\
\text { VDRL essay) } \\
\text { (2) Confirmatory assay } \\
\text { - Treponemal essay } \\
\text { (eg, FTA-ABS, } \\
\text { TP-PA, EIA) }\end{array}$ & $\begin{array}{l}\text { Routine screening } \\
\text { - Rubella lgG }\end{array}$ & Not routine & Not routine \\
\hline $\begin{array}{l}\text { Prenatal } \\
\text { diagnosis }\end{array}$ & $\begin{array}{l}\text { (1) Toxoplasma-specific } \\
\text { immunoglobulin IgG } \\
\text { and IgM antibodies in } \\
\text { maternal serum } \\
\text { (2) USG of fetus } \\
\text { - Intracranial } \\
\text { calcifications, } \\
\text { ventricular dilatations, } \\
\text { hepatic enlargement, } \\
\text { ascites } \\
\text { (3) Toxoplasma DNA in } \\
\text { amniotic fluid }\end{array}$ & $\begin{array}{l}\text { (1) Initial screening } \\
\text { - Non-treponemal } \\
\text { essay (eg, RPR and } \\
\text { VDRL essay) } \\
\text { (2) Confirmatory assay } \\
\text { - Treponemal essay } \\
\text { (eg, FTA-ABS, } \\
\text { TP-PA, EIA) } \\
\text { (3) USG of fetus } \\
\text { - Hepatomegaly, } \\
\text { placentomegaly, } \\
\text { polyhydramnios and } \\
\text { hydrops fetalis }\end{array}$ & $\begin{array}{l}\text { (1) Rubella-specific IgG: } \\
\text { four-fold increase } \\
\text { between acute and } \\
\text { convalescent serum } \\
\text { samples } \\
\text { (2) Positive for rubella- } \\
\text { specific IgM antibodies } \\
\text { (3) Positive rubella virus } \\
\text { culture }\end{array}$ & $\begin{array}{l}\text { (1) CMV DNA PCR and } \\
\text { virus isolation from } \\
\text { amniotic fluid } \\
\text { (2) USG of fetus } \\
\text { - Echogenic bowel, } \\
\text { bilateral periventricular } \\
\text { cerebral calcifications, } \\
\text { hydrocephalus, } \\
\text { microcephaly, fetal } \\
\text { growth retardation, } \\
\text { oligohydramnios or } \\
\text { polyhydramnios, } \\
\text { placentomegaly, } \\
\text { hepatosplenomegaly, } \\
\text { hepatic calcifications, } \\
\text { ascites, or hydrops }\end{array}$ & $\begin{array}{l}\text { (1) Clinical examination } \\
\text { of genital herpes } \\
\text { (2) HSV PCR surface } \\
\text { swab from vesicles }\end{array}$ \\
\hline
\end{tabular}

Abbreviations: $\mathrm{ALT}=$ alanine aminotransferase; $\mathrm{CMV}=$ cytomegalovirus; $\mathrm{CNS}=$ central nervous system; CSF = cerebrospinal fluid; $\mathrm{CXR}=$ chest $\mathrm{X}$-ray; EEG = electroencephalogram; EIA = enzyme immunoassay; FTA-ABS = fluorescent treponemal antibody absorption; HSV = herpes simplex viruses; Ig = immunoglobulin; IV = intravenous; $P C R=$ polymerase chain reaction; $R N A$ = ribonucleic acid; $R P R=$ rapid plasma regain; $R T$-PCR = reverse transcriptase-polymerase chain reaction; TORCH = toxoplasmosis, other (syphilis), rubella, cytomegalovirus, herpes simplex virus; TP-PA = Treponema pallidum particle agglutination; USG = ultrasonography; VDRL = venereal disease research laboratory 
TABLE. (cont'd)

\begin{tabular}{|c|c|c|c|c|c|}
\hline & $\begin{array}{l}\text { Congenital } \\
\text { toxoplasmosis } \\
9,10,13,15,18-20,84\end{array}$ & $\begin{array}{l}\text { Congenital } \\
\text { syphilis }^{9,31,36,41}\end{array}$ & $\begin{array}{l}\text { Congenital } \\
\text { rubella } 9,47,50,53,57\end{array}$ & $\begin{array}{l}\text { Congenital } \\
\text { cytomegalovirus }^{9,22,53,69,71,84}\end{array}$ & $\begin{array}{l}\text { Congenital herpes } \\
\text { simplex virus } \\
\text { infection } \\
22,81,84\end{array}$ \\
\hline $\begin{array}{l}\text { Postnatal } \\
\text { diagnostic } \\
\text { workup }\end{array}$ & $\begin{array}{l}\text { (1) Toxoplasma IgG, IgM, } \\
\text { and IgA in peripheral } \\
\text { blood and CSF } \\
\text { (2) Toxoplasma PCR in } \\
\text { peripheral blood, urine, } \\
\text { CSF, or amniotic fluid }\end{array}$ & $\begin{array}{l}\text { Treponema pallidum in } \\
\text { body fluid or sample from } \\
\text { lesions when viewed by } \\
\text { dark-field microscopy } \\
\text { or fluorescent antibody } \\
\text { staining }\end{array}$ & $\begin{array}{l}\text { (1) Rubella-specific lgM } \\
\text { antibody in cord blood } \\
\text { or neonatal serum } \\
\text { within the first } 6 \\
\text { months of life } \\
\text { (2) Rubella virus RNA } \\
\text { by RT-PCR in } \\
\text { nasopharyngeal swab } \\
\text { or urine } \\
\text { (3) Isolation of rubella virus }\end{array}$ & $\begin{array}{l}\text { Isolation of CMV in the } \\
\text { infant's urine }\end{array}$ & $\begin{array}{l}\text { (1) HSV PCR assay } \\
\text { of surface } \\
\text { specimens (mouth, } \\
\text { nasopharynx, } \\
\text { conjunctivae, anus), } \\
\text { vesicles, CSF, and } \\
\text { whole blood } \\
\text { (2) Scraping of skin } \\
\text { vesicles for HSV } \\
\text { culture (if available) } \\
\text { (3) ALT } \\
\text { (4) CXR } \\
\text { (5) Ophthalmology } \\
\text { exam } \\
\text { (6) Neuroimaging } \\
\text { (7) EEG in neonates } \\
\text { suspected to have } \\
\text { CNS disease }\end{array}$ \\
\hline $\begin{array}{l}\text { Treatment of } \\
\text { infected infant }\end{array}$ & $\begin{array}{l}\text { Symptomatic } \\
\text { - Pyrimethamine, } \\
\text { sulfadiazine, or } \\
\text { clinidamycin and folinic } \\
\text { acid for } 12 \text { months } \\
\text { Asymptomatic } \\
\text { - Pyrimethamine, } \\
\text { sulfadiazine, or } \\
\text { clinidamycin and folinic } \\
\text { acid for } 3 \text { months }\end{array}$ & Penicillin G for 10 days & Supportive care & $\begin{array}{l}\text { Symptomatic infant } \\
\text { - Ganciclovir followed by } \\
\text { valganciclovir for a total of } \\
6 \text { months } \\
\text { Asymptomatic infant } \\
\text { - Supportive care }\end{array}$ & $\begin{array}{l}\text { Disseminated/CNS } \\
\text { diseases } \\
\text { - IV acyclovir for } 21 \\
\text { days } \\
\text { SEM disease } \\
\text { - IV acyclovir for } 14 \\
\text { days } \\
\text { Asymptomatic neonates } \\
\text { who are born to mothers } \\
\text { with HSV infections } \\
\text { close to } \\
\text { - IV acyclovir for } 14 \\
\text { days }\end{array}$ \\
\hline
\end{tabular}

As the majority of neonatal HSV infections are peripartum, reducing neonates' exposure to active genital lesions during delivery is important for prevention of transmission. Active genital HSV lesions or presence of prodromal symptoms at the time of delivery are indications for delivery by Caesarean section, which has been found to be effective in preventing neonatal transmission. ${ }^{76}$ Oral acyclovir or valacyclovir as antiviral suppression therapy, initiated at 36 weeks of gestation, is associated with reduced genital lesions and decreased viral detection by viral culture or PCR at the time of delivery. ${ }^{76,78}$ More studies are required to establish its safety and effectiveness as prophylaxis against neonatal HSV infection.

Counselling on prevention of unprotected sexual contact during pregnancy, especially late pregnancy, may reduce the risk of maternal HSV infection and thus neonatal infection through vertical transmission. ${ }^{80}$

\section{Diagnosing TORCH infection}

'TORCH titres' are often ordered by clinicians who suspect congenital infections; however, various studies have shown that the diagnostic yield is very low if they are not used appropriately. ${ }^{83,84}$ Maternal IgG antibodies can cross the placenta and IgG antibody titres from one blood sample might not be adequate for diagnosis. Therefore, appropriate follow-up testing should be arranged to evaluate the levels of IgG-specific antibody of concern, and whenever possible, isolation of the organism should be attempted. ${ }^{83}$ Targeted specimens and tests rather than a TORCH screen should be sent if the clinical suspicion for a specific congenital infection is strong after reviewing the maternal history and infant's clinical features. The clinical features, antenatal screening, diagnostic testing, and treatment of congenital toxoplasmosis, syphilis, rubella, CMV, and HSV are summarised in the Table. ${ }^{9,10,13,15,18-20,22,31,36,41,47,50,53,57,69,71,81,84}$

\section{Conclusion}

Despite being densely populated, Hong Kong has relatively low rates of congenital infections. Nevertheless, it is important to stay vigilant for infections during pregnancy that may lead to severe disabilities or even death of the fetus. In Hong Kong, comprehensive antenatal services that are available to eligible mothers have been provided free of charge by the public sector in collaboration with the Maternal and Child Health Centres (under the Department of Health) and hospital Obstetrics Departments (under the Hospital Authority). Pregnant women registered 
for the shared care system are entitled to receive regular antenatal check-ups, postnatal services, and close monitoring of the pregnancy.

Prevention is better than intervention, especially in the context of congenital infections. Primary prevention of maternal infection during pregnancy is the key to preventing congenital infections. Effective measures for primary prevention are available, and during the first antenatal visit, screening for rubella, syphilis, and HIV are performed. Available resources should focus on promoting public health.

\section{Author contributions}

All authors had full access to the data, contributed to the study, approved the final version for publication, and take responsibility for its accuracy and integrity.

Concept or design: KL Hon.

Acquisition of data: KKY Leung, A Yeung.

Analysis or interpretation of data: KKY Leung, A Yeung.

Drafting of the article: KL Hon, KKY Leung, A Yeung.

Critical revision for important intellectual content: KL Hon, KKY Leung, AKC Leung, E Man.

\section{Conflicts of interest}

As an editor of the journal, KL Hon was not involved in the peer review process. Other authors have disclosed no conflicts of interest.

\section{Funding/support}

This research received no specific grant from any funding agency in the public, commercial, or not-for-profit sectors.

\section{References}

1. DeVore NE, Jackson VM, Piening SL. TORCH infections. Am J Nurs 1983;83:1660-5.

2. Neu N, Duchon J, Zachariah P. TORCH infections. Clin Perinatol 2015;42:77-103.

3. Stegmann BJ, Carey JC. TORCH infections. Toxoplasmosis, other (syphilis, varicella-zoster, parvovirus B19), rubella, cytomegalovirus (CMV), and herpes infections. Curr Womens Health Rep 2002;2:253-8.

4. Schwartz DA. The origins and emergence of Zika virus, the newest torch infection: what's old is new again. Arch Pathol Lab Med 2017;141:18-24.

5. Nahmias AJ, Walls KW, Stewart, JA, Herrmann KL, Flynt WJ Jr. The ToRCH complex-perinatal infections associated with toxoplasma and rubella, cytomegol- and herpes simplex viruses. Pediatr Res 1971;5:405-6.

6. Fuerst HT. Flame or bird? Pediatrics 1975;56:107.

7. Brumback RA. TORCHES. Pediatrics 1976;58:916.

8. World Health Organization. Global validation of elimination of mother-to child transmission (EMTCT) of HIV and syphilis. 2019. Available from: https://www.who. int/reproductivehealth/congenital-syphilis/emtc-gvac/ en/. Accessed 3 Oct 2019.

9. Wilson CB, Nizet V, Maldonado Y, Remington JS, Klein JO. Remington and Klein's Infectious Diseases of the Fetus and Newborn Infant. 8th ed. Philadelphia: Elsevier Saunders; 2016: 513, 520-5, 675, 677-9, 685-90, 693-4, 729, 732.

10. Montoya JG, Liesenfeld O. Toxoplasmosis. Lancet
2004;363:1965-76.

11. McAuley JB. Congenital toxoplasmosis. J Pediatric Infect Dis Soc 2014;3 Suppl 1:S30-5.

12. Dunn D, Wallon M, Peyron F, Petersen E, Peckham C, Gilbert R. Mother-to-child transmission of toxoplasmosis: risk estimates for clinical counselling. Lancet 1999;353:1829-33.

13. Ko RC, Wong FW, Todd D, Lam KC. Prevalence of Toxoplasma gondii antibodies in the Chinese population of Hong Kong. Trans R Soc Trop Med Hyg 1980;74:351-4.

14. Torgerson PR, Mastroiacovo P. The global burden of congenital toxoplasmosis: a systematic review. Bull World Health Organ 2013;91:501-8.

15. Serranti D, Buonsenso D, Valentini P. Congenital toxoplasmosis treatment. Eur Rev Med Pharmacol Sci 2011;15:193-8.

16. Tamma P. Toxoplasmosis. Pediatr Rev 2007;28:470-1.

17. Wilson CB, Remington JS, Stagno S, Reynolds DW. Development of adverse sequelae in children born with subclinical congenital Toxoplasma infection. Pediatrics 1980;66:767-74.

18. Sever JL, Ellenberg JH, Ley AC, et al. Toxoplasmosis: maternal and pediatric findings in 23,000 pregnancies. Pediatrics 1988;82:181-92.

19. Gay-Andrieu F, Marty P, Pialat J, Sournies G, Drier de Laforte T, Peyron F. Fetal toxoplasmosis and negative amniocentesis: necessity of an ultrasound follow-up. Prenat Diagn 2003;23:558-60.

20. Cortina-Borja M, Tan HK, Wallon M, et al. Prenatal treatment for serious neurological sequelae of congenital toxoplasmosis: an observational prospective cohort study. PLoS Med 2010;7(10). pii: e1000351.

21. Pomares C, Montoya JG. Laboratory diagnosis of congenital toxoplasmosis. J Clin Microbiol 2016;54:2448-54.

22. Kimberlin DW, Brady MT, Jackson MA, editors. Red Book 2018: Report of the Committee on Infectious Diseases. 31st ed. Itasca; American Academy of Pediatrics; 2018: 310-7, 437-48, 459-76, 773-88, 809-19, 8698.

23. Chik TS, Tsang OT. Toxoplasmosis. HIV manual. 4th ed. 2019. Available from: https://hivmanual.hk/d27/. Accessed 7 Oct 2019.

24. Cook AJ, Gilbert RE, Buffolano W, et al. Sources of toxoplasma infection in pregnant women: European multicentre case-control study. European Research Network on Congenital Toxoplasmosis. BMJ 2000;321:1427.

25. Halonen SK, Weiss LM. Toxoplasmosis. Handb Clin Neurol 2013;114:125-45.

26. Jones JL, Krueger A, Schulkin J, Schantz PM. Toxoplasmosis prevention and testing in pregnancy, survey of obstetriciangynaecologists. Zoonoses Public Health 2010;57:27-33.

27. Sagel U, Krämer A. Screening of maternal toxoplasmosis in pregnancy: laboratory diagnostics from the perspective of public health requirements. J Bacteriol Parasitol 2013;S5.

28. Cornu C, Bissery A, Malbos C, et al. Factors affecting the adherence to an antenatal screening programme: an experience with toxoplasmosis screening in France. Euro Surveill 2009;14:21-5.

29. Paquet C, Yudin MH; Society of Obstetricians and Gynaecologists of Canada. Toxoplasmosis in pregnancy: prevention, screening, and treatment [in English, French]. J Obstet Gynaecol Can 2013;35:78-81.

30. World Health Organization. The global elimination 
of congenital syphilis: rationale and strategy for action. 2017. Available from: https://apps.who.int/iris/ handle/10665/43782. Accessed 8 Oct 2019.

31. Special Preventive Programme, Centre for Health Protection, Department of Health, Hong Kong SAR Government. Hong Kong STD/AIDS update-a quarterly surveillance report. Vol 23 No 4, 2017. Available from: https://www.chp.gov.hk/files/pdf/std17q4.pdf. Accessed 8 Oct 2019.

32. Centers for Disease Control and Prevention, US Government. Sexually transmitted disease surveillance. Primary and secondary syphilis-rates of reported cases by state, United States and outlying areas, 2017. Available from: https://www.cdc.gov/std/stats17/figures/37.htm. Accessed 3 Oct 2019.

33. Fiumara NJ. Syphilis in newborn children. Clin Obstet Gynecol 1975;18:183-9.

34. Jenson HB. Congenital syphilis. Semin Pediatr Infect Dis 1999;10:183-94.

35. Herremans T, Kortbeek L, Notermans DW. A review of diagnostic tests for congenital syphilis in newborns. Eur J Clin Microbiol Infect Dis 2010;29:495-501.

36. De Santis M, De Luca C, Mappa I, et al. Syphilis infection during pregnancy: fetal risks and clinical management. Infect Dis Obstet Gynecol 2012;2012:430585.

37. Leung AK, Leong KF, Lam JM. A case of congenital syphilis presenting with unusual skin eruptions. Case Rep Pediatr 2018;2018:1761454.

38. Lago EG, Vaccari A, Fiori RM. Clinical features and followup of congenital syphilis. Sex Transm Dis 2013;40:85-94.

39. Woods CR. Syphilis in children: congenital and acquired. Semin Pediatr Infect Dis 2005;16:245-57.

40. Mannelli L, Perez FA, Parisi MT, Giacani L. A case of congenital syphilis. Emerg Radiol 2013;20:337-9.

41. Public Health Agency of Canada. Government of Canada. Section 5-10: Canadian guidelines on sexually transmitted infections-management and treatment of specific infections-syphilis. 2019. Available from: https://www. canada.ca/en/public-health/services/infectious-diseases/ sexual-health-sexually-transmitted-infections/canadianguidelines/sexually-transmitted-infections/canadianguidelines-sexually-transmitted-infections-27.html. Accessed 3 Oct 2019

42. Alexander JM, Sheffield JS, Sanchez PJ, Mayfield J, Wendel GD Jr. Efficacy of treatment for syphilis in pregnancy. Obstet Gynecol 1999;93:5-8.

43. Sheffield JS, Sánchez PJ, Morris G, et al. Congenital syphilis after maternal treatment for syphilis during pregnancy. Am J Obstet Gynecol 2002;186:569-73.

44. Duthie SJ, King PA, Yung GL, Ma HK. Routine serological screening for syphilis during pregnancy-disposable anachronism or fundamental necessity? Aust $\mathrm{N}$ Z J Obstet Gynaecol 1990;30:29-31.

45. Ho FW. Update on rubella in Hong Kong. Commun Dis Watch 2017;14:66-8.

46. Centre for Health Protection, Department of Health, Hong Kong SAR Government. Number of notifiable infectious diseases by month. 2019. Available from: https://www.chp. gov.hk/en/static/24012.html. Accessed 3 Oct 2019.

47. Leung AK, Hon KL, Leong KF. Rubella (German measles) revisited. Hong Kong Med J 2019;25:134-41.

48. Miller E, Cradock-Watson JE, Pollock TM. Consequences of confirmed maternal rubella at successive stages of pregnancy. Lancet 1982;2:781-4.

49. Dontigny L, Arsenault MY, Martel MJ; Clinical Practice Obstetrics Committee. Rubella in pregnancy. J Obstet Gynaecol Can 2008;30:152-8.

50. Reef SE, Plotkin S, Cordero JF, et al. Preparing for elimination of congenital rubella syndrome (CRS): summary of a workshop on CRS elimination in the United States. Clin Infect Dis 2000;31:85-95.

51. Watson JC, Hadler SC, Dykewicz CA, Reef S, Phillips L. Measles, mumps, and rubella-vaccine use and strategies for elimination of measles, rubella, and congenital rubella syndrome and control of mumps: recommendations of the Advisory Committee on Immunization Practices (ACIP). MMWR Recomm Rep 1998;47:1-57.

52. Rubella vaccines: WHO position paper [editorial] [in English, French]. Wkly Epidemiol Rec 2011;86:301-16.

53. World Health Organization. Manual for the laboratory diagnosis of measles and rubella virus infection Second edition. 2017. Available from: https://www.who.int/ihr/ elibrary/manual_diagn_lab_mea_rub_en.pdf. Accessed 8 Oct 2019.

54. Bart SW, Stetler HC, Preblud SR, et al. Fetal risk associated with rubella vaccine: an update. Rev Infect Dis 1985;7 Suppl 1:S95-102.

55. Centers for Disease Control (CDC). Rubella vaccination during pregnancy-United States, 1971-1988. MMWR Morb Mortal Wkly Rep 1989;38:289-93.

56. Food and Health Bureau, Hong Kong SAR Government. Hong Kong reference framework for preventive care for children in primary care settings. 2012. Available from: https://www.fhb.gov.hk/pho/english/health_ professionals/professionals_preventive_children_pdf. html. Accessed 10 Oct 2019.

57. Lao TT, Suen SS, Leung TY, Sahota DS, Lau TK. Universal rubella vaccination programme and maternal rubella immune status: a tale of two systems. Vaccine 2010;28:2227-30.

58. Boppana SB, Rivera LB, Fowler KB, Mach M, Britt WJ. Intrauterine transmission of cytomegalovirus to infants of women with preconceptional immunity. N Engl J Med 2001;344:1366-71.

59. Lazzarotto T, Guerra B, Gabrielli L, Lanari M, Landini MP. Update on the prevention, diagnosis and management of cytomegalovirus infection during pregnancy. Clin Microbiol Infect 2011;17:1285-93.

60. Cannon MJ. Congenital cytomegalovirus (CMV) epidemiology and awareness. J Clin Virol 2009;46 Suppl 4:S6-10.

61. Boppana SB, Ross SA, Fowler KB. Congenital cytomegalovirus infection: clinical outcome. Clin Infect Dis 2013;57 Suppl 4:S178-81.

62. Centre for Health Protection, Department of Health, Hong Kong SAR Government. Seroprevalence rates of cytomegalovirus antibodies. 2018. Available from: https:// www.chp.gov.hk/en/statistics/data/10/641/701/6445.html. Accessed 5 Oct 2019.

63. Leung AK, Loong EP, Chan RC, Murray HG, Chang AM. Prevalence of cytomegalovirus cervical excretion in pregnant women in Hong Kong. Asia Oceania J Obstet Gynaecol 1989;15:77-8.

64. Kangro HO, Osman HK, Lau YL, Heath RB, Yeung CY, Ng $\mathrm{MH}$. Seroprevalence of antibodies to human herpesviruses in England and Hong Kong. J Med Virol 1994;43:91-6. 
65. Kenneson A, Cannon MJ. Review and meta-analysis of the epidemiology of congenital cytomegalovirus (CMV) infection. Rev Med Virol 2007;17:253-76.

66. Wang C, Zhang X, Bialek S, Cannon MJ. Attribution of congenital cytomegalovirus infection to primary versus non-primary maternal infection. Clin Infect Dis 2011;52:e11-3.

67. Bodéus M, Hubinont C, Goubau P. Increased risk of cytomegalovirus transmission in utero during late gestation. Obstet Gynecol 1999;93(5 Pt 1):658-60.

68. Nigro G. Maternal-fetal cytomegalovirus infection: from diagnosis to therapy. J Matern Fetal Neonatal Med 2009;22:169-74.

69. Leung AK, Sauve RS, Davies HD. Congenital cytomegalovirus infection. J Natl Med Assoc 2003;95:2138.

70. Pass RF, Fowler KB, Boppana SB, Britt WJ, Stagno S. Congenital cytomegalovirus infection following first trimester maternal infection: symptoms at birth and outcome. J Clin Virol 2006;35:216-20.

71. Dollard SC, Grosse SD, Ross DS. New estimates of the prevalence of neurological and sensory sequelae and mortality associated with congenital cytomegalovirus infection. Rev Med Virol 2007;17:355-63.

72. Dahle AJ, Fowler KB, Wright JD, Boppana SB, Britt WJ, Pass RF. Longitudinal investigation of hearing disorders in children with congenital cytomegalovirus. J Am Acad Audiol 2000;11:283-90.

73. Demmler-Harrison GJ. Congenital cytomegalovirus infection: management and outcome. Available from: https://www.uptodate.com/contents/congenitalcytomegalovirus-infection-management-and-outcome. Accessed 10 Oct 2019.

74. Leung AK, Barankin B. Herpes labialis: an update. Recent Pat Inflamm Allergy Drug Discov 2017;11:107-13.

75. Hon KL, Leung TF, Cheung HM, Chan PK. Neonatal herpes: what lessons to learn. Hong Kong Med J 2012;18:602.

76. James SH, Sheffield JS, Kimberlin DW. Mother-to-child transmission of herpes simplex virus. J Pediatric Infect Dis Soc 2014;3 Suppl 1:S19-23.

77. Sauerbrei A. Genital herpes. In: Diagnostics to Pathogenomics of Sexually Transmitted Infections. West Sussex; John Wiley \& Sons Ltd: 2018: 83-99.

78. Kimberlin DW. Herpes simplex virus infections of the newborn. Semin Perinatol 2007;31:19-25.

79. Brown ZA, Selke S, Zeh J, et al. The acquisition of genital herpes during pregnancy. N Engl J Med 1997;337:509-15.

80. Corey L, Wald A. Maternal and neonatal herpes simplex virus infections. N Engl J Med 2009;361:1376-85.

81. Lee NL, Tse IC. V. Major opportunistic infections. Herpes simplex and zoster. 2019. Available from: https://www.aids. gov.hk/pdf/g190htm/25.htm. Accessed 1 Jan 2020.

82. Whitley RJ, Corey L, Arvin A, et al. Changing patterns of herpes simplex virus infection in neonates. J Infect Dis 1988;158:109-16.

83. Leland D, French ML, Kleiman MB, Schreiner RL. The use of TORCH titers. Pediatrics 1983;72:41-3.

84. Lim WL, Wong DA. TORCH screening: time for abolition? J Hong Kong Med Assoc 1994;46:306. 